\title{
MACHINE TRAFFIC AND SOIL PENETRATION RESISTANCE IN GUAVA TREE ORCHARDS $^{1}$
}

\author{
WILSON JOSÉ OLIVEIRA DE SOUZA², DANILO EDUARDO ROZANE ${ }^{2 *}$, HENRIQUE ANTUNES DE SOUZA ${ }^{3}$, \\ WILLIAM NATALE ${ }^{4}$, PAULO ANDRÉ FERNANDES DOS SANTOS ${ }^{2}$
}

\begin{abstract}
The study was conducted in irrigated commercial orchards of 'Paluma' and 'Pedro Sato' guavas, which were mapped with a Garmin GPS unit (Cx60). Sixty five sampling points were marked on a $21 \mathrm{x}$ $21 \mathrm{~m}$ sampling grid. Gravimetric humidity and soil penetration resistance (SPR) were evaluated with the help of an automated penetrometer rod with a type 3 cone at a $45^{\circ}$ angle (maximum SPR 15,100 $\mathrm{kPa}$ ). Data with non -normal distribution were analyzed by geostatistics and interpolation by ordinary kriging. SPR values were higher where machine traffic occurs than on the lines where the crop is planted. There was spatial variability of the SPR among the layers evaluated, with the layer between $0.10-0.20 \mathrm{~m}$, on the line of the machine traffic, presenting a higher SPR $(>4000 \mathrm{kPa})$.
\end{abstract}

Keywords: Psidium guajava L.. Precision agriculture. Soil compacting. Mechanized agriculture.

\section{TRÂNSITO DE MÁQUINAS E RESISTÊNCIA DO SOLO À PENETRAÇÃo EM POMAR DE GOIABEIRAS}

RESUMO - O estudo foi conduzido em pomares comerciais de goiabeiras 'Paluma' e 'Pedro Sato', irrigados, que foram mapeados com GPS de navegação Garmin (Cx60). Houve a demarcação de 65 pontos de amostragem, demarcados em grade amostral de $21 \times 21 \mathrm{~m}$, sendo avaliadas a umidade gravimétrica e a resistência do solo à penetração (RSP), com auxilio de um penetrômetro automatizado, haste com cone tipo 3 com ângulo de $45^{\circ}$ (RSP máximo de $15.100 \mathrm{kPa}$ ). Os dados com distribuição não normal foram analisados por geoestatística e interpolação por krigagem ordinária. Os valores de RSP, onde ocorre o tráfego de máquinas, foi maior do que o avaliado na linha de plantio da cultura. Houve variabilidade espacial da RSP entre as camadas avaliadas, sendo que a camada entre $0,10-0,20 \mathrm{~m}$, na linha do tráfego de máquinas, apresentou a maior RSP $(>4000 \mathrm{kPa})$.

Palavras-chave: Psidium guajava L.. Agricultura de precisão. Compactação do solo. Mecanização agrícola.

\footnotetext{
${ }^{*}$ Corresponding author

${ }^{1}$ Received for publication in $03 / 28 / 2017$; accepted in 04/19/2018.

${ }^{2}$ Department of Agronomy, Universidade Estadual Paulista “Júlio de Mesquita Filho", Registro, SP, Brazil; souza@registro.unesp.br ORCID: 0000-0002-0722-255X, danilorozane@unesp.br - ORCID: 0000-0003-0518-3689, pauloandre.agronomo@gmail.com - ORCID: 0000-0002-9878-1284.

${ }^{3}$ Center of Agricultural Research of the Mid North, Empresa Brasileira de Pesquisa Agropecuária, Teresina, PI, Brazil; henrique.souza@embrapa.br-ORCID: 0000-0002-2209-4285.

${ }^{4}$ Center Agrarian Sciences, Universidade Federal do Ceará, Fortaleza, CE, Brazil; natale@ufc.br - ORCID: 0000-0001-9572-4463.
} 


\section{INTRODUCTION}

Guava has edaphoclimatic fitness for production in all national territory, with Brazil being the biggest global producer of red guava, producing $425 \mathrm{Mg}$ year $^{-1}$ in around of 17.6 thousand ha, with the states of Pernambuco and São Paulo contributing 34.2 and $33.9 \%$ of the total fruit harvested (IBGE, 2017).

In the literature, soil compaction studies are usually related to cereal, fiber and energy crops, especially sugarcane (ARZENO et al., 2014; FAGUNDES; SILVA; BONFIM-SILVA, 2014). Yet, for fruit trees and especially guava, considering the soil production factor, there has been more concern regarding the fertility levels and nutritional management (AMORIM et al., 2015; SOUZA et al., 2016; MONTES et al., 2016). There is little found in the literature on the effects of the intense machine traffic that occurs during cultivation on the physical characteristics of the soil.

In perennial cultures, Souza et al. (2012) compare the soil resistance penetration (SPR) of areas cultivated with guava trees, sugarcane (on the crop line and between the lines) and native forest, observing lower SPR on the crop line and higher in the machine traffic area, indicating that the passage of agricultural machinery between lines of the perennial culture also deserves attention, since it may limit the radicular development of the plant as occurs in sugarcane (FAGUNDES; SILVA; BONFIMSILVA, 2014).

Medeiros et al. (2013) studied the effects of subsoiling depth on citrus orchards cultivated in Red -Yellow Acrisol by observing at 120 days after the subsoiling (done on one side or both sides of the plant) the reduction in SPR values, soil density and non-saturated hydraulic conductivity compared to the control group without subsoiling. It was also observed that the SPR presented positive and significant correlation with the density and degree of compaction, in addition to negative correlation with the macroporosity and the total porosity. The evaluation of the number of fruits per plant, done at 150 days after subsoiling, showed an increase in the number of fruits per area $\left(42 \mathrm{Mg} \mathrm{ha}^{-1}\right.$ in the nonsubsoil area compared to 45 and $55 \mathrm{Mg} \mathrm{ha}^{-1}$ in the subsoil areas on one and both sides of the plant).

Hamza and Anderson (2005) also observed SPR values limited to radicular development of the plants, which according to the authors are larger than $2000 \mathrm{kPa}$. This limit however reflects a general value, since for perennial cultures like guava there are still few studies for inference.

In light of the above, the objective of this work was to study the SPR in an area cultivated with 'Paluma' and 'Pedro Sato' guava trees in the biggest producer region of the state of São Paulo, comparing the values obtained on and in between the lines of the culture (machine traffic region), establishing hypotheses that a) there are differences in SPR values among the positions evaluated; and $b$ ) there exists spatial variability in the SPR in the different layers evaluated.

\section{MATERIAL AND METHODS}

The experiment was developed in commercial plots of adult guava trees (Psidium guajava L.), cultivars Paluma and Pedro Sato, both six years of age and propagated vegetatively. The plants are spaced with $7.0 \mathrm{~m}$ between lines (machine traffic region) and $5.0 \mathrm{~m}$ between trees. The soil was classified as Red-Yellow Acrisol dystrophic.

The orchard is irrigated by dancer-type microsprinklers, with flow rate of $31 \mathrm{~L} \mathrm{~h}^{-1}$, monitored by tensiometry to maintain soil humidity at $60 \%$ of field capacity (FC), with the water drawn from a semi-artesian well. The plots are each about 1.5 ha and located side by side, in the largest guava producing region of São Paulo, in the municipality of Vista Alegre do Alto, with geographic coordinates $21^{\circ} 08^{\prime} \mathrm{S}, 48^{\circ} 30^{\prime} \mathrm{W}$ and altitude of $603 \mathrm{~m}$, indicated according to Alvares et al. (2014) as Aw in the Köppen classification.

For data collection, the area was mapped using a Garmin GPS (model Cx60) with 2 to $6 \mathrm{~m}$ precision, with 65 sampling points marked on a regular sampling grid of $21 \times 21 \mathrm{~m}$ between points.

The variables evaluated were gravimetric humidity and soil humidity along with determining the SPR at the depths of $0-0.10,0.10-0.20,0.20-0.30$ $\mathrm{m}$ and $0.30-0.40 \mathrm{~m}$ using the standard gravimetric method because of the nuances that occur with other methods (BUSKE et al., 2013).

SPR was measured at each georeferenced point until $0.40 \mathrm{~m}$ using an automated penetrometer, model PL5200, made by Falker, with an electronic measurement module with $1.0 \mathrm{~cm}$ precision. The equipment has a metallic rod and a type 3 cone at a $45^{\circ}$ angle, which presents a maximum cone index of $15.100 \mathrm{KPa}$ and $35 \mathrm{~mm} \mathrm{~s}^{-1}$ nominal velocity. The data were stored in the data collection system of the equipment and transferred to the computer via communications cable for processing with the software PenetroLOG by Falker ${ }^{\circledR}$.

Results were subjected to descriptive analyses of the data and the Kolmorogov-Smirnov normality test $(p<0.01)$. Parameters that presented non-normal distribution were subjected to geostatistical analysis (OLIVEIRA et al., 2013). Based on geostatistics, the structure and the spatial dependence were analyzed from the shape of the variogram with its respective parameters $\left(\mathrm{C}=\right.$ spatial variance, $\mathrm{C}_{0}=$ nugget effect, $\mathrm{C}+\mathrm{C}_{0}=$ landing, $\mathrm{a}=$ reach). Both the structure and the spatial dependence between the observed values may be shown by the relationship expressed in Equation 1: 


$$
\gamma(h)=\frac{1}{2}\{\operatorname{Var}[Z(t)-Z(t+h)]\}
$$

where,

$\gamma(\mathrm{h})$ - function defined as semivariogram or intrinsic function;

$1 / 2$ - corresponds to half the mean of the quadratic differences and represents the perpendicular distance from the points in relation to the 45 degree line from the spatial dispersion diagram;

$\mathrm{Z}(\mathrm{t})$ and $\mathrm{Z}(\mathrm{t}+\mathrm{h})$ are the same variable at two different points, separated by a pre-established and constant distance in a defined direction;

$\mathrm{h}$ - pre-established distance interval.

The interpolation of the data for the elaboration of the maps was done with ordinary kriging, with the help of the software GS+ version 9.0. The degree of spatial dependence of the variables studied was calculated using Equation 2 and calculated parameters:

$$
D S D=\frac{C_{0}}{C_{0}+C}
$$

where,

DSD - degree of spatial dependence;

$\mathrm{C}_{0}$ - nugget effect; and

$\mathrm{C}_{0}+\mathrm{C}$ - landings.

The interpretation parameters for the degree of spatial dependence are presented in Table 1.

\begin{tabular}{|c|c|c|c|c|}
\hline \multicolumn{5}{|c|}{ DSD - DEGREE OF SPATIAL DEPENDENCE } \\
\hline Value & STRONG & MODERATE & WEAK & INDEPENDENT \\
\hline Significance & $\begin{array}{l}\quad \leq 0.25 \\
\text { nugget effect less } \\
\text { than or equal to } \\
25 \% \text { of the landing }\end{array}$ & $\begin{array}{l}0.25<\mathrm{DSD} \leq 0.75 \\
\text { nugget effect } \\
\text { represents between } \\
25 \% \text { and } 75 \% \text { of the } \\
\text { landing }\end{array}$ & $\begin{array}{l}\quad 0.75<\mathrm{DSD}<1.0 \\
\text { relationship between nugget } \\
\text { effect and landing is between } \\
75 \% \text { and } 100 \%\end{array}$ & $\begin{array}{l}\qquad=1.0 \\
\text { Relationship between } \\
\text { nugget effect and landing } \\
\text { equal to 1. Pure nugget } \\
\text { effect }\end{array}$ \\
\hline
\end{tabular}

Table 1. Interpretation parameters of the degree of spatial dependence for variables analyzed by the semivariance.

\section{RESULTS AND DISCUSSION}

The average data of gravimetric humidity in the soil profile, taking up 27 randomly selected points in the experimental area, were $11.28 \%$, with no significant differences observed $(p<0.01)$ between the values at the depths studied. Research by Campos et al. (2012) shows the variability of soil humidity tends to be low in areas with the same type of soil, presenting weak spatial dependency. Deurer et al. (2012) however observed lower carbon mineralization in the machine traffic area in New Zealand apple orchards, which the authors attribute to lower microbial activity and infiltration of water, due to greater compaction.

Since there were no differences between the SPRs within the cultivars, the average of the points sampled showed higher resistance in the area of machine traffic, compared to the line of the culture (Table 2), in agreement with the studies done by Souza et al. (2012), who also observed the same SPR behavior in assays done on the same class of soils.

\begin{tabular}{|c|c|c|c|c|c|c|c|c|}
\hline Depth (m) & n-1 & Mean & $E$ & Median & $\mathrm{S}$ & $\mathrm{KS}$ & $\mathrm{pr}<\mathrm{KS}$ & $\mathrm{Sr}$ \\
\hline \multicolumn{9}{|c|}{ culture line (not compacted) } \\
\hline $0.10-0.20$ & 64 & 1673.50 & 93.58 & 1681.80 & 754.45 & 0.1028 & 0.0851 & ns \\
\hline $0.20-0.30$ & 64 & 1879.47 & 121.56 & 1694.70 & 980.09 & 0.1258 & 0.0123 & $*$ \\
\hline $0.30-0.40$ & 64 & 1372.41 & 87.45 & 1199.10 & 705.01 & 0.1275 & 0.0104 & * \\
\hline \multicolumn{9}{|c|}{ transit line (compacted) } \\
\hline $0.10-0.20$ & 64 & 4034.59 & 104.02 & 4001.60 & 838.66 & 0.1579 & 0.0004 & $* *$ \\
\hline $0.20-0.30$ & 64 & 3331.72 & 136.89 & 3370.20 & 1103.68 & 0.0902 & 0.2109 & $\mathrm{~ns}$ \\
\hline $0.30-0.40$ & 64 & 2095.29 & 118.49 & 1915.30 & 955.32 & 0.1747 & 0.0001 & $* *$ \\
\hline
\end{tabular}

Table 2. Results of descriptive analysis of the soil penetration resistance (SPR, $\mathrm{kPa}$ ), in an area cultivated with guava trees.

$\mathrm{n}-1=$ Number of samples per count; Mean = Sample arithmetic mean; $\mathrm{E}=$ standard error of the mean; Mode; $\mathrm{S}=$ standard deviation; $\mathrm{CV}=$ coefficient of variance in $\% ; \mathrm{KW}=$ Kolmorogov-Smirnov normality test (for $\mathrm{p}=0.05) ; \mathrm{pr}=$ probability of the frequency; $\mathrm{Sr}=$ statistical result. $* *=$ significant at the $5 \%$ probability level, presenting non-normal distribution.

Considering the values of SPR on the culture line of the guava trees (Figure 1a), it was observed that the highest values observed were lower than
$2000 \mathrm{kPa}$, which is favorable for the radicular development (HAMZA; ANDERSON, 2005). This is possibly a consequence of adding plant material 
resulting from the successive management of annual pruning, which would reduce the soil density and consequently the SPR, favoring the retention of humidity for a longer period. This in turn favors radicular development, which corroborates the observations of Braida et al. (2010).

The mean value was higher in the machine traffic line (Figure 1e), at the depth of $0.10-0.20 \mathrm{~m}$, reaching $>4000 \mathrm{kPa}$, which is considered limiting to radicular development. According to Hamza and Anderson (2005), SPR values between 2000-3000 kpa present limitations to the radicular development of numerous crops. Becerra et al. (2010) and Deurer et al. (2012) also observe higher SPR in the line between the plants, where machine traffic is intense. For guava, data such as these are practically nonexistent in the literature, yet it is plausible that the guava tree suffers from limitations of radicular development with the SPR values observed in the 0.10-0.20 m layer. Souza et al. (2012) found average
SPR values of $2849.84 \mathrm{kPa}$ and soil density of $1664.0 \mathrm{~kg} \mathrm{~m}^{-3}$ in the machine traffic line in guava orchards, versus $1253.91 \mathrm{kPa}$ and $1577.7 \mathrm{~kg} \mathrm{~m}^{-3}$ on the culture line.

The analyses of regression between the depths studied and the SPR values show polynomial relationships with high coefficients of determination, as shown in Figure 1b.

Considering the data collected on the culture line, as well as the graphs of Figure $1 \mathrm{~b}$, the derivation of the polynomials shows that the maximum SPR in the culture line, $1738.3 \mathrm{kPa}$, would be reached at the depth of $0.29 \mathrm{~m}$, indicating the environment is favorable to the radicular development of the plants in this zone. On the other hand, the maximum SPR value in the machine traffic area occurred at the $0.24 \mathrm{~m}$ depth, reaching a value of $3757.68 \mathrm{kPa}$ (Figure 1b), close to limiting the radicular development of the plants, as reported by some authors (HAMZA; ANDERSON, 2005).
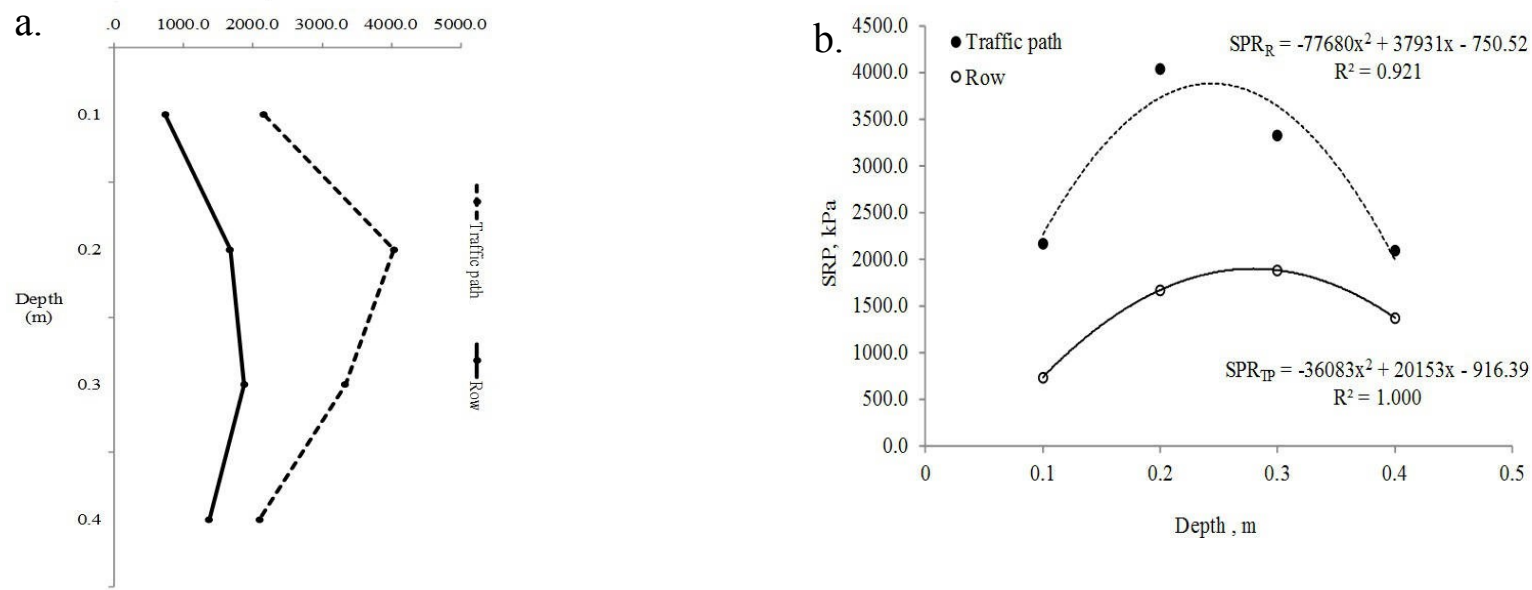

Figure 1. Mean SPR values (a) and analysis of correlation among depths (m) and mean SPR (kPa) (b), on the line of the culture (not compacted) and in the machine traffic area (compacted), in guava tree orchards.

The SPR data on the culture and machine traffic lines were studied by applying descriptive analysis and the Kolmorogov-Smirnov normality test (Table 2).

The SPR data on the culture line presented homogeneity in the higher soil layers and nonnormal distribution in the deepest layers $(0.20-0.30$ $\mathrm{m}$ and $0.30-0.40 \mathrm{~m})$. Analyzing the SPR data on the traffic line, only the $0-0.10 \mathrm{~m}$ and $0.20-0.30 \mathrm{~m}$ layers presented normal distribution. The $0.10-0.20 \mathrm{~m}$ depth tends to receive higher influence from machine traffic in non-mobilized soils, as is the case for notill systems and perennial cultures such as the guava tree, where the line between cultures is maintained with vegetation and the continual addition of large quantities of plant material coming from the pruning of the trees. The superficial layers receive a higher addition of organic material, which according to Braida et al. (2010) tends to diminish the density of the soil and consequently the SPR, whereas the loads transferred to the subsurface layers tend to increase soil densification and SPR.

Iaia, Maia and Kim (2006) emphasize that sandier soils are subject to higher compaction at the greater depths due to deposition of smaller diameter particles, which may justify the results obtained in this experiment conducted in Acrisol.

The variability of the SPR data indicates differences in the behavior of this variable at different points in the study area. The geostatistical technique was applied to the data of SPR, at the depths that presented non-normal distribution by the Kolmorogov-Smirnov test (Table 3). 
W. J. O. SOUZA et al.

Table 3. Semivariogram parameters adjusted for SPR data $(\mathrm{kPa})$, in areas cultivated with guava trees

\begin{tabular}{lcccr}
\hline \multirow{2}{*}{ Parameters } & \multicolumn{4}{c}{ Depth $(\mathrm{m})$} \\
\cline { 2 - 5 } & $0.20-0.30$ & $0.30-0.40$ & $0.10-0.20$ & $0.30-0.40$ \\
\hline & Line of culture & (not compacted) & Line of traffic (compacted) \\
Model & Spherical & Spherical & Linear & Exponential \\
$\mathrm{C}_{0}$ & 61000.00 & 37000.00 & 748459.16 & 20000.00 \\
$\mathrm{C}_{0}+\mathrm{C}$ & 1015000.00 & 528100.00 & 748459.16 & 1098000.00 \\
$\mathrm{~A}_{0}$ & 25.30 & 17.80 & 97.51 & 2.20 \\
$\mathrm{R}^{2}$ & 0.613 & 0.015 & $<0.001$ & 0.010 \\
$\mathrm{RSS}$ & $2.21 \mathrm{E}^{12}$ & $1.49 \mathrm{E}^{11}$ & $3.77 \mathrm{E}^{10}$ & $2.19 \mathrm{E}^{11}$ \\
GDE & 0.06 & 0.07 & 1.0 & 0.018 \\
\hline
\end{tabular}

Variables analyzed and adjusted by statistical models: $\mathrm{C}_{0}=$ nugget effect; $\mathrm{C}_{0}+\mathrm{C}=$ landing; $\mathrm{A}_{0}=$ (autocorrelation) proportion of the variation explained by the distance between the samples; $\mathrm{R}^{2}=$ proportion of the variation explained by the best fit of the model; DSD = degree of spatial dependence calculated as a function of the nugget effect and of the landing calculated for the model defined by the variable.

The depths that presented non-normal distribution on the culture line $(0.10-0.20 \mathrm{~m}$ and 0.30 $0.40 \mathrm{~m}$ ) adjusting to the spherical linear models (Figures $2 \mathrm{a}$ and $2 \mathrm{~b}$ ), presented the nugget effect in both the cases. A strong degree of spatial dependence (DSD) was noted among the points sampled, especially in the $0.20-0.30 \mathrm{~m}$ layer, which had a

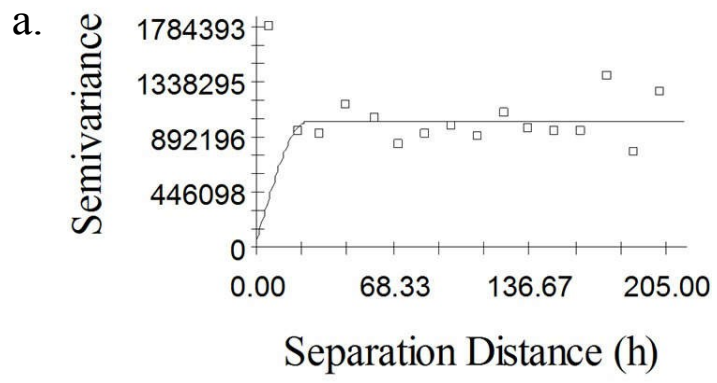

value of 0.06 , as well as for the $0.30-0.40 \mathrm{~m}$ layer, which presented DSD equal to 0.07 .

The reach values for the culture line data were higher than those of the sampling mesh at the of $0.10-0.20 \mathrm{~m}$ depth and lower at the $0.30 \mathrm{~m}-0.40 \mathrm{~m}$ depth, possibly because of the higher quantity of roots, which would lead to higher SPR variability at this depth.



Figure 2. Semivariogram of the soil penetration resistance (SPR) on the line of the culture (non-compacted) at the depths of $0.20-0.30 \mathrm{~m}(\mathrm{a})$ and $0.30-0.40 \mathrm{~m}(\mathrm{~b})$ in a guava tree orchard.

The SPR data on the line of traffic show nonnormal distribution at the depths of $0.20-0.30 \mathrm{~m}$ and $0.30-0.40 \mathrm{~m}$ adjusting to the spherical model (Figure 3a) and exponential model (Figure 3b), with the nugget effect observed in both the cases. A strong degree of spatial dependence (DSD) was noted among the points showed in the $0.30-0.40 \mathrm{~m}$ layer, whose value was 0.018 . Independence was noted among the points sampled in the $0.20-0.30 \mathrm{~m}$ layer, with DSD equal to 1.00 .

The reach distance for the data on the transit line was $2.20 \mathrm{~m}$ at the greatest depth $(0.30-0.40 \mathrm{~m})$, which was less than that of the sampling mesh, whereas at the $0.10-0.20 \mathrm{~m}$ depth the pure nugget effect was observed.

b.

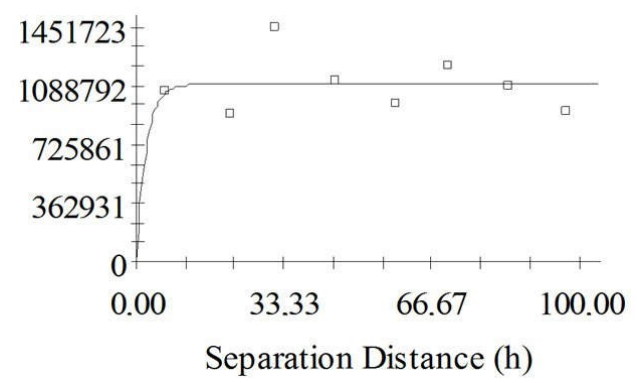

Figure 3. Semivariogram of the soil penetration resistance (SPR) on the line of agricultural machine traffic (compacted), at the depths of $0.10 \mathrm{~m}$ (a) and $0.20-0.30 \mathrm{~m}$ (b), in guava tree orchards. 
These data corroborate Campos et al. (2012), who also found a pure nugget effect of the reach at greater depths, which was also greater than that of the sampling mesh in an area cultivated with cassava. In a cultivation of almond trees (Prunus amygdalus), perennials and cultivated plants such as guava trees in lines, Becerra et al. (2010) observed the increase of apparent density and nugget effect in layers of the subsoil, when the lines between the crops were subjected to the transit of tractors. In areas of guava cultivation, little information is available in the literature, so other studies are necessary to compare with the results obtained in this work.

\section{CONCLUSIONS}

The SPR values were higher where machine traffic occurs than on the line of guava tree plantings.

There is spatial variability of the SPR between the layers evaluated. The layer between $0.10-0.20 \mathrm{~m}$ in the machine traffic line presents the highest SPR $(>4000 \mathrm{kPa})$.

\section{ACKNOWLEDGMENTS}

We thank the company Indústria de Polpas $e$ Conservas VAL Ltda for allowing us to use their area for performing the experiment.

\section{REFERENCES}

ALVARES, C. A. et al. Köppen's climate classification map for Brazil. Meterologische Zeitschrift, Stuttgart, v. 22, n. 6, p. 711-728, 2014.

AMORIM, D. A. et al. Adubação nitrogenada e potássica em goiabeiras 'Paluma': I Efeito na produtividade e na qualidade dos frutos para industrialização. Revista Brasileira de Fruticultura, Jaboticabal, v. 37, n. 1, p. 201-209. 2015.

ARZENO, J. L. et al. Variabilidade espacial da resistência à penetração na superfície do solo em sistemas de manejo. Revista Brasileira de Ciências Agrárias, Recife, v. 9, n. 3, p. 343-352. 2014.

BECERRA, A. T. et al. Soil compaction distribution under tractor traffic in almond (Prunus amigdalus L.) orchard in Almería España. Soil \& Tillage Research, Amsterdan, v. 107, n. 1, p. 49-56, 2010.

BRAIDA, J. A. et al. Teor de carbono orgânico e a susceptibilidade à compactação de um Nitossolo e um Argissolo. Revista Brasileira de Engenharia
Agrícola e Ambiental, Campina Grande, v. 14, n. 2 , p. 131-139, 2010.

BUSKE, T. C. et al. Avaliação do desempenho do método das pesagens para a determinação da umidade do solo. Revista Brasileira de Agricultura Irrigada, Botucatu, v. 7, n. 6, p. 340-348, 2013.

CAMPOS, M. C. C. et al. Variabilidade espacial da resistência do solo à penetração e umidade em áreas cultivadas com mandioca na região de humaitá, AM. Revista Agroambiente, Boa Vista, v. 6, n. 1, p. 916, 2012.

DEURER, M. et al. Can minor compaction increase soil carbon sequestration? A case study in a soil under a wheel-track in an orchard. Geoderma, Amsterdan, v. 183, n. 1, p.74-79, 2012.

FAGUNDES, E. A. A; SILVA, T. J. A; BONFIMSILVA, E. M. Desenvolvimento inicial de variedades de cana-de-açúcar em Latossolo submetidas a níveis de compactação do solo. Revista Brasileira de Engenharia Agrícola e Ambiental, Campina Grande, v. 18, n. 2, p. 188-193, 2014.

HAMZA, M. A.; ANDERSON, W. K. Soil compaction in cropping systems: a review of the nature, causes and possible solutions. Soil \& Tillage Research, Amsterdam, v. 2, n. 2, p. 121-145, 2005.

IAIA, A. M.; MAIA, J. C. S; KIM, M. E. Uso do penetrômetro eletrônico na avaliação da resistência do solo cultivado com cana-de-açúcar. Revista Brasileira de Engenharia Agrícola e Ambiental, Campina Grande, v. 10, n. 2, p. 523-530, 2006.

\section{INSTITUTO BRASILEIRO DE GEOGRAFIA E ESTATÍSTICA - IBGE. Produção Agrícola Municipal. Disponível em: http:// www.sidra.ibge.gov.br/bda/tabela/listabl.asp? $\mathrm{c}=1613 \& \mathrm{z}=\mathrm{p} \& \mathrm{o}=18$. Acesso em: $15 \mathrm{fev} .2017$.}

MEDEIROS, J. C. et al. Deep subsoiling of a subsurface-compacted typical hapludult under citrus orchard. Revista Brasileira de Ciência do Solo, Viçosa, v. 37, n. 4, p. 911-919, 2013.

MONTES, R. M. et al. Nitrogen and potassium fertilization in a guava orchard evaluated for five cycles: soil cationic balance. Revista Brasileira de Ciência do Solo, Viçosa, v. 40, n. 1, p. 1-11, 2016.

OLIVEIRA, I. R. et al. Modelagem geoestatística das incertezas da distribuição espacial do fósforo disponível no solo, em área de cana-de-açúcar. Revista Brasileira de Ciência do Solo, Viçosa, v. 37, n. 6, p. 1481-1491, 2013.

SOUZA, H. A. et al. Guava waste to sustain guava 
(Psidium guajava) agroecosystem: nutrient -balanceconcepts. Frontiers in Plant Science, Melbourne, v. 7, n. 1, p. 1-13, 2016.

SOUZA, W. J. O. et al. Evaluation of soil management and use in an ultisol in a guava orchard in comparison with a sugarcane field and native forest area. Acta Horticulturae, Leuven, v. 959, n. 1, p. 173-177, 2012. 